\title{
100 YEARS OF WELLCOME - AN UNUSUAL COMPANY CELEBRATES ITS CENTENARY
}

(News release by Hanel Public Relations Consultants (Pty) LId.)

$\mathbf{N}^{o}$ ot many companies are owned by a charitable trust or have a Nobel Prize winner amongst their research scientists. These are two of the unusual features of the Wellcome Foundation, which celebrates its centenary this year. Wellcome is owned by the Wellcome Trust, a charitable organisation which utilises all money made out of the company's operations in relief of suffering and disease, to further the relief of suffering and disease.

From its inception the company set out on a road characterised by research. Henry Wellcome later called it "In Pursuit of Excellence - purification, formulation, analytical control and precision of standardisation', a philosophy which today still lies behind the company's endeavours.

In South Africa the Group honoured Sir Henry Wellcome at a function held in Johannesburg at which the Minister of Industries and of Commerce and Consumer Affairs, Dr the Honourable S W van der Merwe, delivered the main address. "Wellcome holds an altogether anomalous position in the pharmaceutical industry," the Minister said.

"It is blamed along with the rest of the industry for all the real and supposed malpractices against humanity, but it is ironical that it has been owned since 1935 by a charitable trust. The profits made by the various operating companies are either used for further development of the activities or for the purpose of financing grants to universities and other institutions for projects related to human and animal health." Dr van der Merwe referred to one newspaper survey which described the basis of the Wellcome Trust in these words: "The Wellcome principle is a simple one, all the money made out of the company's operations in the relief of suffering and disease shall be used to further the relief of suffering and disease."

Although Burroughs took the initiative in forming the company, it was Henry Wellcome who was the driving force. He was a perfectionist and assumed or expected all members of his staff to be of a similar mind.

His "In Pursuit of Excellence" never faltered - it was conveyed to all his staff and became an integral and enduring part of his company's philosophy and prac- tice. The rigorous manufacturing standards and the extensive quality control procedures to which Wellcome products are subjected are set out in the Wellcome Code of Good Manufacturing Practice - a code that many countries have accepted as their industry standard. Today Wellcome as a Group employs a staff of nearly 1000 on quality control alone.

Henry Wellcome believed in freedom of opportunity - freedom to reach defined objectives. He offered his scientists good facilities and organisation and freedom to publish. This policy attracted to his laboratories many young scientists who subsequently achieved international recognition for their work.

In his address the Minister of Industries and of Commerce and Consumer Affairs paid tribute to Wellcome's contribution to medical research. "What amazes one is the outstanding success of the Wellcome Foundation in developing new pharmaceutical compounds," he said. "In contrast to only four basic new drugs invented in the first 55 years of its existence as a private orientated company, the list of successes since Wellcome became a charitable trust in 1935 is quite impressive. Continued success is ensured by the spending of large amounts of money and energy on research and development. This year alone an amount of R72 million has been set aside for this purpose."

Henry Wellcome loved to travel. South Africa was one of the first countries visited by him, where a local company was established. In the early 1900's after a visit to Cape Town, he wrote a five-page handwritten report motivating the establishment of a branch. Henry Wellcome returned again in 1902 to set up a local branch. A year later the name 'Burroughs Wellcome' appeared proudly on the facade of a building at 5 Loop Street.

In 1955, a Johannesburg office was opened. Two years later the Cape Town operation was moved to Clare House in Johannesburg and in 1959 the first fullscale Secondary Pharmaceutical plant was established at 130 Main Street.

In 1972, the whole Wellcome Group, which by this time included Coopers and Calmic, was brought under one roof at a new Southern Africa headquarters at Spartan, Kempton Park. 